\title{
Bimbingan Motivasi bagi Mahasiswa pada Pembelajaran Bulutangkis
}

\author{
Tjung Hauw Sin
}

Fakultas Ilmu Keolahragaan, Universitas Negeri Padang

$\equiv$ e-mail: thj_sin@yahoo.com

\begin{abstract}
Abstrak
Penelitian ini bertujuan untuk mengidentifikasi kondisi motivasi mahasiswa pada pembelajaran bulutangkis. Jenis penelitian yang akan digunakan dalam penelitian ini adalah penelitian deskriptif dengan sampel sebanyak 50 orang mahasiswa jurusan Kepelatihan FIK UNP yang mengikuti perkuliahan bulutangkis pada semsester Januari-Juni 2017 yang dipilih dengan teknik proportional random sampling. Berdasarkan hasil penelitian maka dapat disimpulkan bahwa secara keseluruhan motivasi mahasiswa jurusan Kepelatihan FIK UNP mengikuti mata kuliah bulutangkis pada semester Januari-Juni tahun akademik 2017 pada umumnya sedang dan beberapa pada katagori sangat rendah, rendah, tinggi dan sangat tinggi. Berdasarkan hasil penelitian tersebut peneliti merekomendasikan diperlukan adanya bimbingan untuk meningkatkan dan mengembangkan motivasi bagi mahasiswa dengan tujuannya dapat membantu pencapaian prestasi belajar yang maksimal.
\end{abstract}

Kata Kunci: motivasi, pembelajaran bulutangkis, motivasi atlit

Copyright (C) 2017 IICET (Indonesia) - All Rights Reserved

Indonesian Institute for Counseling, Education and Therapy (IICET)

\section{PENDAHULUAN}

Pendidikan pada Perguruan Tinggi merupakan proses yang dapat dimanfaatkan mahasiswa untuk mengembangkan potensi diri (Indrajit \& Djokopranoto, 2006). Hal ini sesuai dengan tujuan pendidikan yang telah dirumuskan dalam Undang-undang Nomor 20 Tahun 2003 tentang Sistem Pendidikan Nasional Pasal 1 Butir 1 yang menjelaskan sebagai berikut; "Pendidikan adalah usaha sadar dan terencana untuk mewujudkan suasana belajar dan proses pembelajaran agar peserta didik secara aktif mengembangkan potensi dirinya untuk memiliki kekuatan spiritual keagamaan, pengendalian diri, kepribadian, kecerdasan, akhlak mulia, dan keterampilan yang diperlukan dirinya, masyarakat, bangsa dan negara”.

Inti dari pendidikan adalah belajar (Barlian, 2013). Tidak ada pendidikan tanpa kegiatan belajar. Pendidikan merupakan suatu indikator yang digunakan untuk kemajuan suatu negara yang mendukung pembangunan dan merupakan konstruk kompetensi suatu negara. Melalui pendidikan manusia dapat menghadapi dan memecahkan masalah serta tantangan yang dihadapinya (Sauri, S. 2009). Berbicara tentang pendidikan tidak dapat dipisahkan dengan upaya-upaya yang harus dilakukan untuk menciptakan sumber daya manusia yang kompeten dan berkualitas.

Salah satu upaya tersebut dikaitkan dengan pencapaian tujuan pendidikan adalah dengan mengembangkan motivasi yang dimiliki oleh peserta didik (Aritonang, 2008). Motivasi, baik itu sifatnya intrinsik maupun ekstrinsik harus terarah pada suatu sasaran tertentu, karena tanpa adanya sasaran tertentu, maka arah perilaku seseorang menjadi tidak jelas. Motivasi mengacu pada adanya kebutuhan seseorang yang dilandasi oleh kepribadian individu yang bersangkutan (Hutapea, B. 2010), karenanya motivasi tidak bisa digeneralisasikan bagi semua orang melainkan harus ditinjau secara khusus dari satu individu ke individu lainnya (Himam, 2004). 
Pelaksanaan perkuliahan pada Perguruan Tinggi diperlukan adanya suatu dorongan yang timbul dalam diri dan luar diri mahasiswa. Dorongan-dorongan itu disebut dengan motivasi (Hou \& Lynch, 2017). Melalui belajar individu dapat mengembangkan potensi yang ada dalam dirinya. Oleh karena itu mahasiswa perlu belajar dengan sungguh-sungguh, didasari motivasi untuk mempersiapkan dan mengikuti kegiatan belajar serta mengerjakan tugas dan menindaklanjuti materi perkuliahan yang telah dipelajari.

Motivasi perlu ada pada setiap mahasiswa (Sri Mendari, 2013), termasuk pada mahasiswa jurusan Kepelatihan Fakultas Ilmu Keolahragaan. Motivasi olahraga adalah keseluruhan daya penggerak (motif-motif) di dalam diri individu yang menimbulkan kegiatan berolahraga, menjamin kelangsungan latihan dan memberi arah pada kegiatan latihan untuk tujuan yang dikehendaki (Firmansyah, 2009).

Salah satu mata kuliah pada Fakultas Ilmu Keolahragaan (selanjutnya disingkat FIK) di Universitas Negeri Padang (selanjutnya disingkat UNP) adalah mata kuliah bulutangkis. Untuk mencapai tujuan dari perkuliahan bulutangkis maka harus ada persiapan yang dilakukan. Persiapan-persiapan tersebut diwujudkan agar mahasiswa dapat menguasai materi perkuliahan yang diajarkan. Sehingga mahasiswa dapat mencapai prestasi yang memuaskan khususnya di bidang bulutangkis

Prestasi merupakan salah satu tujuan yang ingin dicapai (Hutapea, 2010) dalam mata kuliah bulutangkis. Dengan adanya mata kuliah bulutangkis maka diharapkan prestasi mahasiswa dalam olahraga cabang bulutangkis akan semakin meningkat. Dalam mencapai prestasi tersebut banyak hal yang harus dipersiapkan, salah satunya dan yang terpenting adalah kondisi psikologis yang baik (Yulianto \& Nashori, 2006). Keadaan psikologi yang sedang tidak baik dapat berpengaruh pada kondisi fisik (Kusumowardhani, 2009).

Temuan di lapangan menunjukkan bahwa telah terjadi penurunan minat belajar mahasiswa dalam perkuliahan bulutangkis yang ditandai dengan tidak hadirnya dalam perkuliahan, dan ketidakaktifan mahasiswa dalam proses pembelajaran serta ketika diadakan diskusi mahasiswa belum mampu memahami materi yang diberikan. Sehingga berdampak terhadap penurunan prestasi mahasiswa pada cabang olahraga bulutangkis.

Hal demikian berarti beberapa mahasiswa kurang termotivasi untuk mengikuti perkuliahan, sehingga berbagai upaya diarahkan untuk meningkatkan motivasi mahasiswa dalam belajar. Kurangnya motivasi mahasiswa dalam mengikuti mata kuliah bulutangkis dapat dipengaruhi oleh beberapa faktor yang berbeda pada tiap individu. Oleh karena itu diperlukan perhatian dan pembinaan khusus untuk meningkatkan motivasi mahasiswa dalam mengikuti mata kuliah bulutangkis.

Faktor psikologis dari setiap mahasiswa juga bisa menjadi penyebab dari mahasiswa untuk aktif atau tidaknya dalam proses perkuliahan. Faktor-faktor kepribadian sering dilupakan padahal pada cabang-cabang olahraga tertentu memegang peranan penting bahkan seringkali sebagai faktor utama yang mempengaruhi prestasi yang diharapkan (Gunarsa, 1989). Aspek psikologi seperti motivasi, sikap, konsentrasi, tingkat ketenangan dan kepercayaan diri adalah faktor-faktor penting dalam membuat mahasiswa berprestasi (Hakim, 2005). Aspek motivasi memegang peranan penting dalam kejiwaan seseorang (Yanti \& Warsito, 2013), sebab motivasi merupakan salah satu faktor penentu seseorang melakukan kegiatan (Aritonang, 2008) yaitu sebagai pendorong tingkah laku manusia sehingga dengan adanya motivasi seseorang dapat mendorong dirinya untuk lebih giat berlatih dan mencapai hasil yang maksimal.

Mahasiswa yang mengikuti mata kuliah bulutangkis tentu memiliki motivasi tersendiri (Subarjah, $\mathrm{H}$. 2016), baik yang dipengaruhi oleh motivasi instrinsik (dari dalam diri) ataupun ekstrinsik (dari luar). Keragaman motivasi yang dimiliki mahasiswa dapat mempengaruhi proses perkuliahan dan berdampak pada hasil kuliah yang akan diperoleh pada akhir semester.

\section{METODOLOGI}

Jenis penelitian yang akan digunakan dalam penelitian ini adalah penelitian deskriptif. Yang menjadi sampel dalam penelitian ini adalah mahasiswa jurusan Kepelatihan FIK UNP yang mengikuti perkuliahan bulutangkis pada semsester Januari-Juni 2017 yaitu sebanyak 50 orang yang dipilih dengan teknik proportional random sampling. Data dianalisis dengan menggunakan teknik analisis deskriptif. 
HASIL DAN PEMBAHASAN

Berdasarkan hasil pengolahan data, maka hasil penelitian ini dapat digambarkan table 1 sebagai berikut:

Tabel 1 Motivasi mahasiswa pada pembelajaran bulutangkis

\begin{tabular}{cccc}
\hline Kriteria & $\mathbf{f}$ & \% \\
\hline Sangat Tinggi & 7 & 14 \\
Tinggi & 6 & 12 \\
Sedang & 23 & 46 \\
Rendah & 13 & 26 \\
Sangat Rendah & 1 & 2 \\
\hline
\end{tabular}

Motivasi mahasiswa pada pembelajaran bulutangkis pada umumnya berada pada kategori sedang yang artinya 23 dari 50 orang mahasiswa yang menjadi sampel penelitian memiliki motivasi pada kategori sedang dalam mengikuti pembelajaran bulutangkis dengan persentase $46 \%$. Selanjutnya 13 orang mahasiswa memiliki motivasi pada kategori rendah dengan persentase $26 \%$ dan 7 orang mahasiswa memiliki motivasi pada kategori sangat tinggi dengan persentase 14\%. Selanjutnya 6 orang mahasiswa memiliki motivasi pada kategori tinggi dengan persentase $12 \%$, kemudian 1 orang mahasiswa memiliki motivasi pada kategori sangat rendah dengan persentase 2\%. Hal demikian berarti bahwa kecenderungan motivasi mahasiswa pada pembelajaran bulutangkis yang tinggi dengan persentase 26\% (13 orang), umumnya yang sedang 46\% (23 orang) dan masih ada $28 \%$ (14 orang) memiliki persentase yang rendah.

Berdasarkan pemaparan tabel 1, secara umum motivasi mahasiswa pada pembelajaran bulutangkis umumnya berada pada kategori sedang dan masih ada yang memiliki motivasi yang rendah. Hal ini menunjukkan bahwa mahasiswa cukup memiliki ketertarikan pada pembelajaran bulutangkis yang ditampilkan melalui keaktifan dalam proses pembelajaran. Mahasiswa yang masih memiliki motivasi yang rendah perlu diberikan bimbingan motivasi. Mahasiswa akan mampu untuk mandiri, proaktif, kritis, dan kreatif dalam pembelajaran kuncinya yaitu adanya motivasi yang tinggi.

Motivasi merupakan suatu dorongan yang timbul oleh adanya rangsangan-rangsangan dari dalam (internal) maupun dari luar (eksternal) sehingga seseorang berkeinginan untuk mengadakan perubahan tingkah laku atau aktivitas tertentu menjadi lebih baik dari keadaan sebelumnya (Lamatenggo \& Hamzah, 2012). Selanjutnya, motivasi menjadi sangat penting untuk meningkatkan dorongan individu mencapai citacitanya.

Motivasi dapat ditingkatkan melalui materi pembelajaran yang memiliki bobot ilmiah tinggi, karena adanya kecenderungan mahasiswa untuk meniru dan mencontoh dosen yang berkualitas (Dariyo, 2004). Motivasi mahasiswa yang tinggi akan membantu meningkatkan prestasi belajar mahasiswa (Ali, M. 2009). Sebagaimana dijelaskan bahwa hubungan yang baik antara dosen dan mahasiswa memberikan pengaruh terhadap prestasi belajarnya dimana mahasiswa merasa aman untuk berkoordinasi dengan dosen berkaitan dengan materi perkuliahan yang diajarkan.

Berdasarkan temuan penelitian dimana motivasi mahasiswa jurusan Kepelatihan FIK UNP dalam mengikuti mata kuliah bulutangkis pada semester Januari-Juni 2017 sebagian besar adalah sedang. Idealnya dalam mengikuti suatu pembelajaran mahasiswa memiliki motivasi yang tinggi. Motivasi memegang peranan penting dalam kejiwaan seseorang, sebab motivasi merupakan salah satu faktor penentu seseorang melakukan kegiatan.

Motivasi sebagai pendorong tingkah laku manusia sehingga dengan adanya motivasi seseorang dapat mendorong dirinya untuk lebih giat berlatih dan mencapai hasil yang maksimal (Kurniawan \& Kurniawan, 2013). Oleh karena itu perlu untuk meningkatkan motivasi agar tercapainya hasil belajar yang tinngi. Jika mahasiswa tidak memiliki motivasi yang tinggi dalam mengikuti pembelajaran, maka akan berdampak pada menurunnya prestasi mahasiswa pada bidang bulutagkis dan juga akan berpengaruh pada hasil kuliah yang akan diperoleh pada akhir semester. 


\section{SIMPULAN DAN SARAN}

Berdasarkan hasil penelitian maka dapat disimpulkan bahwa secara keseluruhan motivasi mahasiswa jurusan Kepelatihan FIK UNP mengikuti mata kuliah bulutangkis pada semester Januari-Juni tahun akademik 2017 pada umumnya sedang dan beberapa pada katagori rendah. Berdasarkan hasil penelitian tersebut diperlukan adanya bimbingan untuk meningkatkan dan mengembangkan motivasi bagi mahasiswa mata kuliah bulutangkis jurusan Kepelatihan FIK UNP. Diharapkan kepada (1) Dosen Matakuliah Bulutangkis, agar senantiasa meningkatkan upaya bimbingan motivasi bagi mahasiswa agar semakin tingginya motivasi mahasiswa dalam mengikuti pembelajaran. (2) Mahasiswa diharapkan agar mahasiswa mampu meningkatkan motivasi menjadi lebih tinggi lagi, guna untuk mencetak prestasi pada bidang bulutangkis dan juga agar memperoleh nilai yang bagus pada akhir semester, dan (3) Peneliti selanjutnya melakukan penelitian lanjutan sejenis disarankan untuk meneliti dengan memperhatikan variabel-variabel yang berpengaruh terhadap motivasi, dan upaya untuk meningkatkan motivasi.

\section{DAFTAR PUSTAKA}

Ali, M. (2009). Pengembangan media pembelajaran interaktif mata kuliah medan elektromagnetik. Jurnal Edukasi Elektro, 5(1).

Aritonang, K. T. (2008). Minat dan motivasi dalam meningkatkan hasil belajar siswa. Jurnal Pendidikan Penabur, 7(10), 11-21.

Barlian, I. (2013). Begitu Pentingkah Strategi Belajar Mengajar Bagi Guru? In Forum Sosial (Vol. 6, pp. 241246). Jurusan Pendidikan Ilmu Pengetahuan Sosial Fakultas Keguruan Dan Ilmu Pendidikan Universitas Sriwijaya.

Dariyo, A. (2004). Pengetahuan Tentang Penelitian Dan Motivasi Belajar Pada Mahasiswa. Jurnal Psikologi, $2(1)$.

Firmansyah, H. (2009). Hubungan Motivasi Berprestasi Siswa dengan Hasil Belajar Pendidikan Jasmani. Jurnal Pendidikan Jasmani Indonesia, 6(1).

Gunarsa, S. D. (1989). Psikologi olahraga. Jakarta: Gunung Mulia.

Hakim, T. (2005). Belajar secara efektif: Niaga Swadaya.

Himam, F. (2004). Interaksi dan motivasi belajar mengajar. Jakarta: Rajawali Pers.

Hou, J., \& Lynch, R. (2017). A correlative study of motivation for learning Chinese according to academic achievement and parental encouragement among grade four to grade six students at Ladprao Bilingual School (LBS), Bangkok, Thailand. Scholar, 8(2).

Hutapea, B. (2010). Studi komparatif tentang motivasi berprestasi pada atlet kempo propinsi DKI Jakarta ditinjau dari keribadian. judul" Peran Sikap, Norma Subjektif, dan Persepsi Kendali Perilaku Dalam Memprediksi Intensi Wanita Melakukan Pemeriksaan Payudara Sendiri”. Kesehatan perempuan merupakan sesuatu yang penting, terlebih lagi perempuan, khususnya di Indonesia, dewasa ini dapat menjadi pemimpin (khalifah). Oleh karenanya, artikel hasil penelitian dari Arum dan Mangkunegara tersebut dapat kita pandang berkontribusi terhadap upaya penyadaran dan edukasi terhadap perempuan untuk, 199.

Hutapea, B. (2010). Studi komparatif tentang motivasi berprestasi pada atlet kempo propinsi DKI Jakarta ditinjau dari keribadian. judul" Peran Sikap, Norma Subjektif, dan Persepsi Kendali Perilaku Dalam Memprediksi Intensi Wanita Melakukan Pemeriksaan Payudara Sendiri”. Kesehatan perempuan merupakan sesuatu yang penting, terlebih lagi perempuan, khususnya di Indonesia, dewasa ini dapat menjadi pemimpin (khalifah). Oleh karenanya, artikel hasil penelitian dari Arum dan Mangkunegara tersebut dapat kita pandang berkontribusi terhadap upaya penyadaran dan edukasi terhadap perempuan untuk, 199.

Indrajit, R. E., \& Djokopranoto, R. (2006). Manajemen perguruan tinggi modern. Andi.

Kurniawan, H. A., \& Kurniawan, A. (2013). Motivasi Mahasiswa Program Studi PJKR FIK UNY Mengikuti Mata Kuliah Pilihan Sepaktakraw Pada Semester VI Tahun Akademik 2012/2013. Fakultas Ilmu Keolahragaan.

Kusumowardhani, R. (2009). Pendampingan Psikologis Bagi Atlet Cilacap dalam Pekan Olah Raga Provinsi Jawa Tengah Tahun 2009 di Solo (Studi Preliminer). Psikobuana Volume 1 Nomor 2 ini menghadirkan lima buah artikel. Artikel pertama ditulis oleh Reni Kusumawardhani, dengan judul "Pendampingan Psikologis Bagi Atlet Cilacap dalam Pekan Olah Raga Provinsi Jawa Tengah Tahun 2009 di Solo (Studi Preliminer)". Sebagaimana diketahui, Psikologi Olahraga merupakan salah satu bidang psikologi yang belum banyak dioptimalkan perannya dalam dunia olahraga di Indonesia. Dalam konteks inilah, studi, 73. 
Lamatenggo, N., \& Hamzah, U. B. (2012). Teori Kinerja dan Pengkurannya: Jakarta: PT. Bumi Aksara

Sauri, S. (2009). Revitalisasi Pendidikan Sains dalam Pembentukan Karakter Anak Bangsa untuk Menghadapi Tantangan Global. In Seminar Nasional Pendidikan Sains.

Sri Mendari, A. (2013). Aplikasi teori hierarki kebutuhan Maslow dalam meningkatkan motivasi belajar mahasiswa. Widya Warta, 34(01).

Subarjah, H. (2016). Hubungan antara Kebugaran Jasmani dan Motivasi Belajar dengan Prestasi Belajar Mahasiswa. Sosiohumanika, 9(1).

Yanti, R. I., \& Warsito, B. E. (2013). Hubungan karakteristik perawat, motivasi, dan supervisi dengan kualitas dokumentasi proses asuhan keperawatan. Jurnal Manajemen Keperawatan, 1(2).

Yulianto, F., \& Nashori, F. (2006). Kepercayaan diri dan prestasi atlet tae kwon do daerah istimewa Yogyakarta. Jurnal Psikologi Undip, 3(1), 55-62 